\title{
Chapter 22 \\ Socioeconomic Residential Segregation and Income Inequality in Bogotá: An Analysis Based on Census Data of 2005
}

\section{Alexandra López Martínez and Owen Eli Ceballos Mina}

\begin{abstract}
Residential segregation is both a cause and consequence of socioeconomic inequalities. Since the 1990s, segregation patterns in Latin American cities have changed significantly. This is related to major urban transformations caused by privatization policies related to urban development, commercialization, and real estate activity. The main purpose of this chapter is to study residential socioeconomic segregation in the city of Bogotá, Colombia in 2005, using educational attainment as an indicator of socioeconomic status while considering the drivers of segregation during the 1990s. We also introduce a brief analysis of the relationship between residential segregation and inequality based on a model that allows replicating the income distribution of the population using census variables. This chapter shows that residential segregation in Bogotá is related to per capita income inequality, however, segregation may be caused by the dynamics of land and housing markets rather than inequality.
\end{abstract}

Keywords Socioeconomic residential segregation • Income inequality • Bogotá

\subsection{Introduction}

Residential segregation has become relevant in recent decades due to the economic, social, and cultural effects of urban development which depend on the capitalist accumulation model (De Mattos 2002, 2012). Territories are not homogeneous in their material or symbolic components and Latin American cities are no exception.

Electronic supplementary material The online version of this chapter (https://doi.org/10.1007/978-3-030-64569-4_22) contains supplementary material, which is available to authorized users.

\footnotetext{
A. López Martínez ( $\square)$

Technological of Antioquia University Institution, Medellín, Colombia

e-mail: alexanlm87@gmail.com

O. E. Ceballos Mina

Autonomous Metropolitan University, Unit Azcapotzalco, Mexico City, Mexico e-mail: oecm@azc.uam.mx
} 
Segregation patterns may change according to the characteristics of each city which, while adjusting under a neoliberalism logic, reveal the differential distribution of population groups, both at a macro- and micro-scale (Sabatini 2003). Distribution of population groups is determined by government, market, and population interactions in the social production of space, the actions of these actors that territorializes, sectorizes, and segregates people as a result of the social and economic relationships developed in their territories.

This chapter focuses on residential segregation of educational groups, and how it is related to income inequality. Addressing this relation is supported by literature that indicates that inequalities and segregation tend to reproduce each other (Elorza 2013). This happens because economic inequality is attributed to the labor market, which creates varied living conditions for different demographic groups, including differences in access to land and housing, which causes diverse residential location patters, i.e., segregation between groups with different economic resources. Also, belonging to a certain social group allows or constrains access to opportunities to improve one's welfare (Kaztman 2003) which occurs depending on the role different groups play in the social division of labor.

In this chapter, two dimensions of residential segregation between educational groups are considered. First, at the urban scale, characterized through the analysis of location quotients of the main demographic groups with high educational attainment; second, block scale level analysis is used for obtaining the socio-spatial distribution of population groups. The proceeding two sections address the theoretical background and changes in socio-spatial segregation patterns in the city of Bogotá. The methodology is presented in the third section, including data sources and variables used for measuring segregation and inequality. The fourth section presents the results. Finally, conclusions are drawn from the main findings.

\subsection{Changes in Socio-spatial Segregation Patterns}

When communities are socially segregated or intentionally separated from other social groups, we are referring to the phenomenon of socio-spatial segregation (Kaztman 2003). This phenomenon is often produced and reproduced through the institutional control of resources which allow barriers that restrict the physical and social contact of internally homogeneous groups with other groups which have different characteristics based on income, education, or any other characteristic (De Queiroz 2003).

Segregation as a concept has been approached from differences in residential location and unequal access to land and housing. In the first case, within the framework of classic social ecology theory from the Chicago School in the early twentieth century, the concept of segregation was developed by Robert Ezra Park and Ernest Burgess as a means to analyze the "natural concentration" of certain groups in an urban population. Thereafter, segregation was considered as a neutral topic of urban 
ecology for characterizing spatial differentiation of population groups in the cities (Salas 2008).

With the arrival of Modern Social Ecology in the 1950s, quantitative studies of the urban social structure and socio-spatial segregation were carried out. The precursors were Shevky and Williams (1949) and Shevky and Bell (1955) who, under a deductive analysis of homogeneous social areas in the urban environment, categorized demographic groups by their social rank, that is, by their socioeconomic situation, by variable urbanization which is related to the family situation, and by their ethnic characteristics (Buzai 2003, p. 43). Thus, it was possible to analyze the social differentiation and stratification of a specific group, by means of several variable techniques. Since the 1970s, segregation has been analyzed within the unequal access framework by the classic urban theorists-Lefebvre, Lojkine, and Castells- ${ }^{1}$ who agree that residential segregation is revealed by the organizational form of space in capitalist societies.

However, segregation is a phenomenon that has been present since the time when cities emerged and is not only present in capitalist societies. Urban segregation is expressed differently depending on the age in which it is studied. Until the 1980s, the traditional pattern of socio-spatial segregation in Latin America was characterized by the residential localization of high-income population groups near the historical downtown in a concentrated way, while low-income populations were concentrated in suburbs and dangerous areas of the city (Sabatini 2003; Sabatini and Cáceres 2005). There are additional layers that make segregation patterns more complex, including (a) the demographic diversity of middle-income populations in the historical downtown, (b) a duality of the city with stigmatized areas related to poverty conditions, and (c) other zones that have emerged in the modern city.

On its own, patterns of segregation are expressed in the urban structure where (a) high-income population groups are becoming increasingly scattered throughout the city and not concentrated in a high rent area in the city center, (b) construction of new commercial and service sub-centers are located outside the traditional center with the aim of gaining new markets, (c) a rise in land prices that isolate low-income groups into suburban zones with low-cost housing, and (d) urban renovation in the deteriorated downtown areas in the form of gentrification (Sabatini 2003).

This new spatial expression emerged in the 1990s, at the beginning of the neoliberal era when land started to be treated like merchandise since. It was at this point when the government downgraded its role to that of a regulator by means of laws and norms, and real estate and other market actors obtained a stronger role in the housing market, especially when it came to the supply of new housing (Janoschka and Glasze 2003; Moura 2003; Sabatini and Cáceres 2005; Torres et al. 2009). Such dynamics have allowed the extension of existing affluent neighborhoods and the

\footnotetext{
${ }^{1}$ Lefebvre (1976, 1978a, b) pointed out that segregation was an implicit analytical category in the space's production and appropriation, while the sociologist Lojkine (1979) considered that the concept guided an investigative work and Castells (2008) established a definition of urban segregation based upon dimensions, intra homogeneous status and different from others, and as a process because such inequalities tend to perpetuate through time.
} 
dispersion of the concentrated elites to the suburbs due to capital concentration and the liberalization of land markets (Sabatini and Cáceres 2005).

In this context, it can be said that housing access in Bogotá is determined by the laws of: "(...) housing distribution and therefore, produces re-grouping in function of the social capability of people in the capitalist system" (cf. Castells 2008, p. 203), in which a user-client-consumer relationship develops (Aprile and Mosquera 1984). Then, it is possible to state that socio-spatial segregation appears when there is a contradiction between the production of space in the city and private appropriation (Alessandri 2013), where land and housing become a trade value rather than a usage asset.

To be more specific, three main agents intervene in the segregation process, the government, the real estate market, and the population (Ábramo 2003). These agents are related to the three relevant causes that produce such process: the economic inequality between people generated in the labor market, land valorization through the real estate market, and the urban legislation regulated by the state (Torres et al. 2003).

The living conditions of different social groups are attributable to the labor market since it is partly responsible for economic inequality, which leads to unequal access to land and housing and, therefore, residential segregation between different demographic groups. Members of different social groups may or may not have access to opportunities for improving their welfare (Kaztman 2003) and, as a consequence, are differentially positioned across urban socio-spatial dividing lines.

On its part, the geography of opportunity theory suggests that the physical proximity between varied population groups (based on their socioeconomic level, race, religion, etc.) could overcome social problems by means of opportunity structures and positive socialization (Howell-Moroney 2005). However, this approach presents a neoliberal bias since it indicates that the proximity between poor and rich areas encourages social mixing, which is needed in order to improve the standard of living of the poor (Ruiz-Tagle and López 2014). This approach ignores the fact that behind such an "opportunity" is an implicit market-oriented assumption (Ruiz-Tagle 2016), which does not take into account the role that institutions must carry on to secure a just redistribution of resources and opportunities that mitigate the formation of enclaves. In this way, the activities of the three main urban agents and the consequent spatial order of cities also contribute to the reproduction of urban socio-spatial inequalities.

\subsection{Residential Segregation in Bogotá}

The phenomenon of residential segregation in Bogotá is not new, and some studies have corroborated that from the colonial model to the fragmentary model that characterizes the city today (Bäbr and Borsdorf 2005), the city has shifted from a macro to a micro-scale of segregation (Secretaría Distrital de Planeación 2011). Since the 1950s, 
Bogotá has been characterized by urban expansion driven by population displacement due to the search for better opportunities and by migration caused by political violence in rural areas (Aliaga and Álvarez 2010).

In the colonial era, the city (until 1920), maintained its spatial configuration around the main square, which matches a concentric residential differentiation model (Cardeño 2007) characterized by the fact that high-income population resided near the administrative, commercial, and political zone. It can be said that segregation at that time was low. Later, technological advancements in transport, road networks, and the increase of cars in the city paved the way to the growth of industry in the city. In the late 1930s, Bogotá shifted from an economy based on commercial capitalism to an industrial one, with its spatial model characterized by sectoral differentiation focused on growth around and along main roads and to areas with sufficient workforce, following a north-south expansion and leading to a mixed commercial and residential land use (Salas 2008). In other words, industrial activities were located along the main roads and to areas with a sufficient workforce, leading to a mixed commercial and residential land use. It is important to stress that the city's expansion in this era was not continuous since working-class neighborhoods were built in a scattered way over the Bogotá savanna. High-income residential neighborhoods consolidated to the north of the city with the aim of ratifying its economic and social power, while neighborhoods in the southern zone provided shelter to lower socioeconomic groups (Cardeño 2007).

Around the mid-twentieth century, due to the rural in-migration to the city caused by the civil war, ${ }^{2}$ population growth intensified, shaping the segregation at a macroscale because the newly arrived people did not have sufficient income to buy a house. The construction of houses for those displaced from violence took place in peripheral areas and at the same time, the high-income population was more worried about its social status - from the center to the northeast-as it happened in other Latin American countries (Aliaga and Álvarez 2010). The high-income population had low a population density, residing near green areas such as the Oriental Hills, and in neighborhoods with quality infrastructure, aspects that commonly determine higher land and housing values (Salas 2008). So, low-income populations clustered in the formal and informal settlements in the peripheral zone, generating irregular urbanization patterns in the form of neighborhoods that lacked basic public services (Aliaga and Álvarez 2010). In this manner, a dual city was developed, with a rich north and a poor south.

As a consequence of this duality, some zones grew in value and other urban zones lost value, and the functioning of a private market for the production and construction of new housing sorted people into those neighborhoods according to the buyer's payment capacity. However, since the 1980s, due to the promotion of gated housing complexes for the upper middle class, fitted with private security and high-end equipment to, the center welcomed again such a population. As a result, a mixture of rich and poor people with different characteristics and population

2 The population of the city of Bogotá increased from 330,000 to 1,130,000, between 1938 and 1958 , the urbanized area went from 2,514 to $8,084 \mathrm{~m}^{2}$ in the said years (Salas 2008). 
densities emerged. Nevertheless, this micro-scale segregation is embedded within the persistent macro-scale segregation in Bogotá (Aliaga and Álvarez 2010).

In relation with land and house prices in different localities, Amézquita et al. (2017) discovered that higher housing prices were found in Usaquen in the Northand Chapinero in the Northeast, while lower prices were found in Bosa, Ciudad Bolívar, Usme, and San Cristóbal in the Southwest. This situation again reinforces the link between land and housing prices, and segregation, especially related to the broader socioeconomic stratification ${ }^{3}$ of the city. For example, there is diversified stratification in the neighborhoods of Usaquen and Suba in the North and Chapinero in the Northeast. However, higher social classes (4 and 5) predominate in the north area, while in the South there is less stratification (1 and 2) and are located in the localities Bosa, Ciudad Bolívar, Usme, and San Cristóbal (Amézquita et al. 2017). This shows an important correlation between the price of land and housing, and the socioeconomic stratification of the city (Fig. 22.1). It must be noted that Bogotá is the capital of Colombia, with an approximate population of 6840116 habitants in 2005 (Rubiano, 2017). The city has an administrative political division of 19 localities. Among the most notable locality is Chapinero, where the city's historic core is located (Annex 1).

Educational level is another factor related to segregation. Dureau et al. (2012) found a positive relationship between the level of education and the social status index (SSI). ${ }^{4}$ Table 22.1 shows a relationship between educational level and social class in 1993 and 2005. Households heads with a higher level of education mainly belong to the higher SSI classes (5 and 6), and household heads with lower levels of education mainly belong to the lower social SSI classes (Dureau et al. 2012).

Furthermore, while it is true that in Colombia, residential segregation has been studied more from an economic view via the dimensions proposed by Massey and Denton (1988), it is also true that this phenomenon has been addressed from the perspective of land prices in Bogotá (Fuentes 2010), social housing in Medellín (Velasquez 2011), and urban development and segregation in the Municipality of Barrancabermeja (Molina 2008). The main findings for segregation in Bogotá from a socioeconomic view are the following. According to the residential segregation index, housing prices are a key factor that increases segregation. The socioeconomic segregation index shows that the segregation is high. We used large spatial units to measure segregation, using smaller spatial units would show even higher levels of segregation (Sabatini et al. 2008, pp. 24-25). Therefore, some authors (Secretaría Distrital de Planeación 2007, 2013) propose that public policies must be oriented to diminish both exclusionary and discriminatory practices in order to reduce the gap between the rich and the poor.

\footnotetext{
${ }^{3}$ It is a classification that seeks differentially to grant subsidies in the payment of domiciliary public services.

${ }^{4} \mathrm{SSI}=$ Average years of education of household members over 15 years of age/Overcrowding of housing. This is a proxy variable of the social class in which every home in the city is located (Salas 2008).
} 
Square meter housing prices 2012 (COP)

$2103,747-3000,300$

$300042,300-623739,000$

$623739,000-1213930,000$

$1213930,000-3232415,000$

Localities

Transmilenio

stations

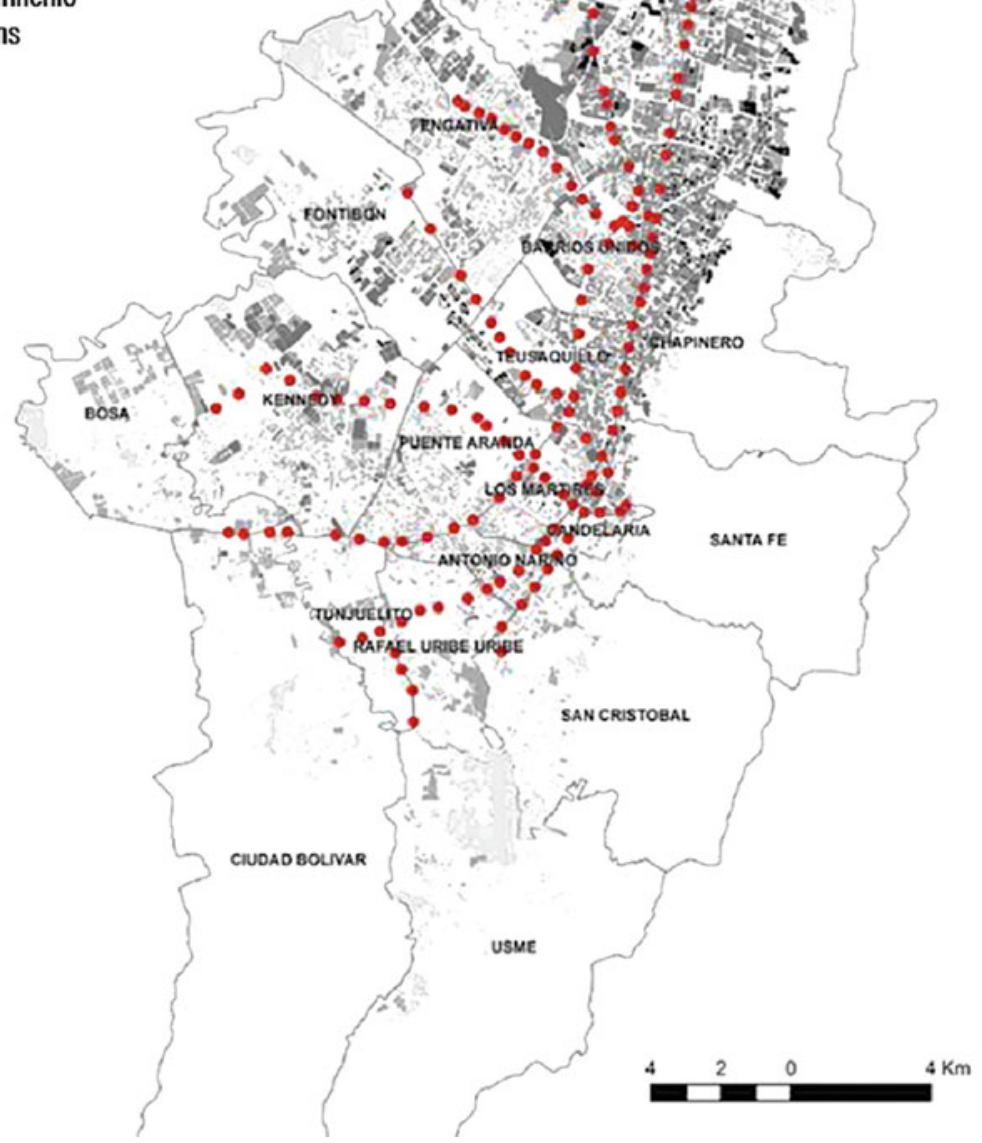

Fig. 22.1 Square meter housing prices in Bogotá, 2012. Source Amézquita et al. (2017, pp. 275276) 


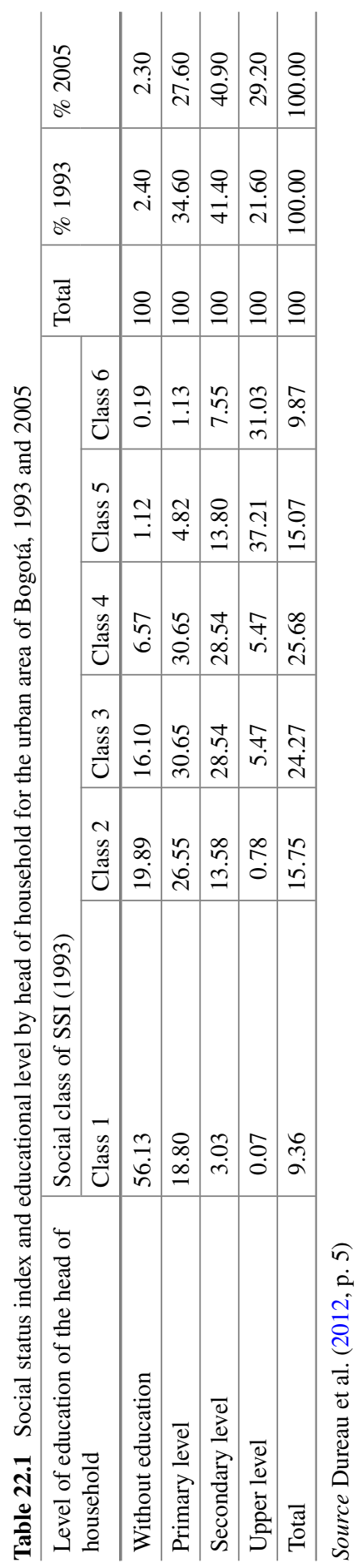


For its part, the analyses of residential segregation indexes (spatial autocorrelation) reveal spatial dependence, that is, higher valuations of property or land are linked with their residents and that in turn have high neighborhood values of said variable (Secretaría Distrital de Planeación 2013). Another investigation renders that educational level is a key determinant for a higher residential segregation in both Bogotá and Medellín (Aliaga and Álvarez 2010; Medina et al. 2008), which means that population groups are spatially localized and segregated according to their human capital.

\subsection{Methodology}

In order to be able to determine segregation levels and their relationship with income inequality for the city of Bogotá, we rely on two data sources. The 2005 Population Census which covers nearly 6.8 million persons living in more than 35 thousand blocks of the city, and the 2007 Life Quality Survey-Bogotá that provides information on the income of people. Both data sources are published by the Statistics National Administrative Department (DANE, by its Spanish acronym). The census data was made compatible with the census codes of the National Geostatistics Framework established by the DANE, so that it was possible to form a harmonized data set for analyzing the spatial differentiation of the variables studied. We used educational attainment of the household head as the variable to analyze segregation because in the Colombian census, income is not available. However, education level also differentiates, separates, and segregates population. Education levels may also have a positive effect on segregation as it is "the main way of social mobility and privileged scope for the social integration of new generations" (Kaztman 2001).

Table 22.2 shows an increase of people with the highest level of education (higher and postgraduate), while the proportion of people with basic levels of education (preschool and primary) decreased during the period between the two censuses of 1993 and 2005 in Bogotá. Since there is no income variable in the 2005 census, we

Table 22.2 Variation of population groups by education level in Bogotá, 1993-2005

\begin{tabular}{l|l|l|l|l|l|l}
\hline \multirow{2}{*}{ Education level } & \multicolumn{2}{l}{1993} & \multicolumn{2}{l}{2005} & \multicolumn{2}{l}{$\begin{array}{l}\text { Intercensal variation } \\
1993-2005\end{array}$} \\
\cline { 2 - 7 } & $\mathrm{N}$ & $\%$ & $\mathrm{~N}$ & $\%$ & $\mathrm{~N}$ & $\%$ \\
\hline Higher and postgraduate & 507.064 & 24.9 & 1003.857 & 32.5 & 496.793 & 98.0 \\
\hline High school & 962.309 & 47.2 & 1429.509 & 46.2 & 467.200 & 48.5 \\
\hline Preschool and primary & 547.770 & 26.8 & 624.484 & 20.2 & 76.714 & 14.0 \\
\hline None & 23.165 & 1.1 & 35.349 & 1.1 & 12.184 & 52.6 \\
\hline Total & 2.040 .308 & 100 & 3093.199 & 100 & 1052.891 & 51.6 \\
\hline
\end{tabular}

Source Fuentes (2012, p. 283) 
constructed a representative variable for average income distribution at the blocklevel based on the 2007 Life Quality Survey-Bogotá. It is harmonized with the Colombian population and housing census and it provides and an additional perspective for analyzing the relationship between residential segregation and inequality.

Dissimilarity index $(D I)$ was used ${ }^{5}$ to determine city-wide levels of segregation. The DI compares levels of segregation between specific groups (Massey and Denton 1988), and we express it in an unitary interval where values near zero imply low segregation and one indicates high segregation. Its interpretation suggests that the group's proportion in focus must change its spatial unit with respect to the rest of the population in the same area, in order to accomplish an equal distribution (Martori et al. 2006). However, spatial indexes such as the DI don't reveal statistical significance (Garrocho and Campos-Alanís 2013). For this reason, we used the spatial autocorrelation index in order to determine the existence of a random distribution between adjacent units for the same variable, as well as the Morán Global Index (IGM, by its Spanish acronym) ${ }^{6}$ (Reardon and O'Sullivan 2004) which allows researchers to determine the existence of clustered population groups in a given geographical space.

In order to measure inequality in light of the non-available information regarding income and employment structure, we built a representative variable of average income distribution at the block scale using microdata from the 2007 Bogotá Quality of Life Survey and the exercise was replicated with the 2005 census. We estimated a linear regression model with the 2007 Bogotá Quality of Life Survey data to identify the weight or factors of population and housing characteristics regarding the average income distribution at the block level. Then the obtained weights were applied to the census variables in order to estimate a measure for average income distribution for the 2005 census. $^{7}$

This exercise was initiated with an estimation, adjustment, and aggregation at the block level (geographical scale) for the variable of the 2007 Bogotá Quality

${ }^{5} D=\frac{1}{2} \sum_{i=1}^{n} \mid \frac{x_{i}}{X}-\frac{y_{i}}{Y}$

where: $x_{i}=$ group's population in the spatial unit $i$;

$X=$ group's population in the whole city;

$y_{i}=$ reference group's population in the spatial unit $i$; and.

$Y=$ reference group's population in the whole city.

${ }^{6} I=\frac{n \sum_{i=1}^{n} \sum_{i=1}^{n} w_{i j}\left(y_{i}-y\right)\left(y_{j-y}\right)}{\left(\sum_{i=1}^{n}\left(y_{i}-y\right)^{2}\right)\left(\sum_{i \neq 1} \sum w_{i j}\right)}$

where: $y_{i}=$ variable or attribute value en each spatial unit $i$;

$y_{j}=$ variable or attribute value in each adjacent spatial unit $i$;

$w_{i j}=$ proximity between spatial units $i$ and $j$; and

$n=$ number of spatial units.

7 This exercise has its empiric background in the estimation of socio-economic levels (NSE, by its Spanish acronym) carried on by the Mexican Association of Market Intelligence and Public Opinion Agencies (AMAI, by its Spanish acronym) in order to classify households by socio-economic groups highly correlated with income levels (AMAI 2018). 
of Life Survey in order to make them equivalent with those in the 2005 census. $^{8}$ The response variable selected in the model was the per capita income logarithm per block. A correlation analysis was made between the available variables and the response variable in order to identify those variables with higher explanatory power. The model considered 17 variables grouped in three analytical dimensions in order to explain the income: $(i)$ human capital and employment, (ii) demographic structure, and (iii) housing and services. Table 22.3 presents an estimation of all variables. With this set of determinants, the least weighted squares regression model was estimated for the average per capita current income, in order to consider the expansion factor associated with each household in the 2007 Bogotá Quality of Life Survey (see Annexes 2 and 3). The weights estimated by the model are used in the estimation of per capita income with the 2005 census data in order to map the spatial distribution of income in the neighborhoods of Bogotá (Fig. 22.4) and compares the income map with the educational attainment map (Fig. 22.3). ${ }^{9}$

\subsection{Inequality and Socio-spatial Segregation in Bogotá}

Before establishing the relationship between income inequality and residential segregation in Bogotá, a brief review is made of the evolution of the Gini Index at a national level and for Bogotá in the last twenty years. Figure 22.2 shows that income inequality has decreased both in Bogotá and in the country, but to different degrees. The index has changed in a range between 59 points in the second half of 2000s (Colombia's highest Gini level was in 2008) and 49 towards the end of the analysis period (lowest level in 2017 both for country and Bogotá). Bogotá shows less inequality than the whole country except in the period between 2002 and 2006. However, SanchezTorres (2017) and Hoyos (2016) state that Bogotá always was in the top 5 of the most unequal cities in Colombia. Bogotá shows a remarkable decrease in inequality between 2006 and 2012, and since then the Gini Index value indicated no significant variations. By 2017, the city's index value was almost equal to the national average. Nevertheless, in 2018 the level of national inequality showed a rebound in contrast with a decreasing tendency between 2008 and 2017.

When considering the location quotient (see Fig. 22.3), household heads with a high education level are concentrated in the Northeast of the city, where there is a medium to high socioeconomic stratification (Secretaría Distrital de Planeación 2007). It is very unlikely to find households heads with low education level in this

\footnotetext{
${ }^{8}$ Even though income information is asked and recollected in tables at individual level, ECV-B2007 is a representative survey with micro data available at household level. On other hand, the access to census' information has block as maximum disaggregation level given the confidentiality and information protection parameters.

${ }^{9}$ In Bogotá, the population density in 2005 was 175.4 people per hectare and the population density of household head was 50 per hectare (Alcaldia Mayor de Bogotá; Secretaria Distrital de Planeación 2010). However, the population density of the head of household may change depending on his geographical location.
} 
Table 22.3 Estimated weights of variables for per capita income

\begin{tabular}{|c|c|c|c|}
\hline Dependent variable & Dimension & Explicative variables & Estimated weights \\
\hline \multirow[t]{17}{*}{$\begin{array}{l}\text { Per capita income } \\
\text { logarithm }\end{array}$} & \multirow[t]{6}{*}{$\begin{array}{l}\text { Human capital and } \\
\text { employment }\end{array}$} & $\begin{array}{l}\text { 1. Persons with less than } \\
\text { complete elementary } \\
\text { education }\end{array}$ & $-0.017 * * *(4.02)$ \\
\hline & & $\begin{array}{l}\text { 2. Persons with } \\
\text { elementary education }\end{array}$ & $-0.027 * * *(5.45)$ \\
\hline & & $\begin{array}{l}\text { 3. Persons without } \\
\text { complete high school }\end{array}$ & $-0.016^{* * *}(3.82)$ \\
\hline & & $\begin{array}{l}\text { 4. Persons with high } \\
\text { school }\end{array}$ & $-0.007 *(1.79)$ \\
\hline & & $\begin{array}{l}\text { 5. Persons with higher } \\
\text { education }\end{array}$ & $0.073 * * *(18.0)$ \\
\hline & & $\begin{array}{l}\text { 6. Number of employed } \\
\text { persons }\end{array}$ & $0.066 * * *(23.8)$ \\
\hline & \multirow[t]{5}{*}{$\begin{array}{l}\text { Demographic } \\
\text { structure }\end{array}$} & $\begin{array}{l}\text { 7. Persons under } 15 \text { years } \\
\text { old }\end{array}$ & $0.015 * * *(4.18)$ \\
\hline & & $\begin{array}{l}\text { 8. Persons over } 65 \text { years } \\
\text { old }\end{array}$ & $-0.015 * * *(3.14)$ \\
\hline & & $\begin{array}{l}\text { 9. Number of domestic } \\
\text { employees }\end{array}$ & $0.128 * * *(8.85)$ \\
\hline & & $\begin{array}{l}\text { 10. Size of average } \\
\text { household }\end{array}$ & $-0.013^{*}(1.68)$ \\
\hline & & 11. Total population & $-0.339 * * *(4.75)$ \\
\hline & \multirow[t]{6}{*}{ Housing and services } & 12. Telephone availability & $0.031 * * *(6.57)$ \\
\hline & & $\begin{array}{l}\text { 13. No sewage system } \\
\text { availability }\end{array}$ & $-0.128 * * *(11.52)$ \\
\hline & & 14. House & $-0.060 * * *(2.67)$ \\
\hline & & 15. Apartment & $-0.049 * *(2.19)$ \\
\hline & & 16. Room & $-0.097 * * *(4.26)$ \\
\hline & & $\begin{array}{l}\text { 17. Another residential } \\
\text { type }\end{array}$ & $-0.075 * * *(2.92)$ \\
\hline
\end{tabular}

Absolute value of $t$-statistic in parenthesis. ${ }^{* *} p<0.01,{ }^{* *} p<0.05, * p<0.10$

Source Elaboration by the authors based on ECV-B2007 (DANE 2007)

urban zone. Block-level segregation, as indicated by the DI, between household heads with a high education level is 0.57 , while block-level segregation household heads with a low educational level is 0.67 . These results are as expected, considering previous research which used the same index for Bogotá (cf. Salas 2008; Aliaga and Álvarez 2010).

The previous results contrast with those of the Morán Global Index (see Annex 4), which shows that the probability for each group to be distributed randomly in the city is low and household heads with a high education level are the most residentially segregated (0.44), clustering in Bogotá's northeast neighborhoods (See Fig. 22.4). 


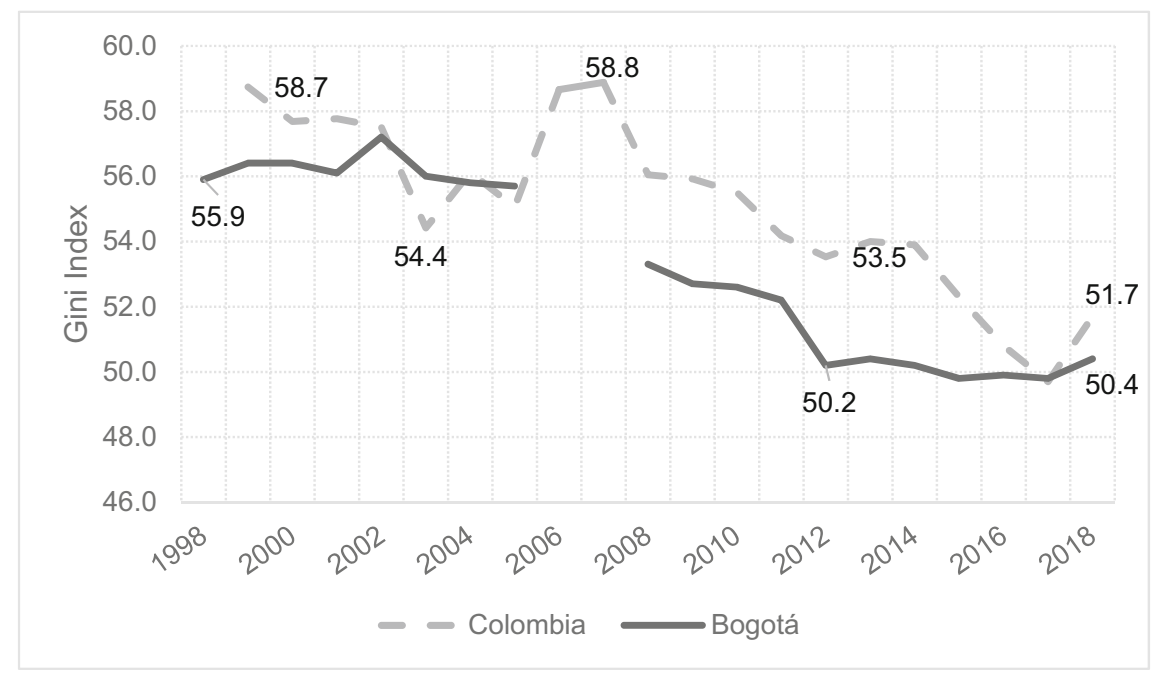

Fig. 22.2 Evolution of inequality in Colombia and Bogotá 1998-2018. Source Elaboration by the authors base on National Planning Department (DNP) report with data from Continuous Employment Surveys
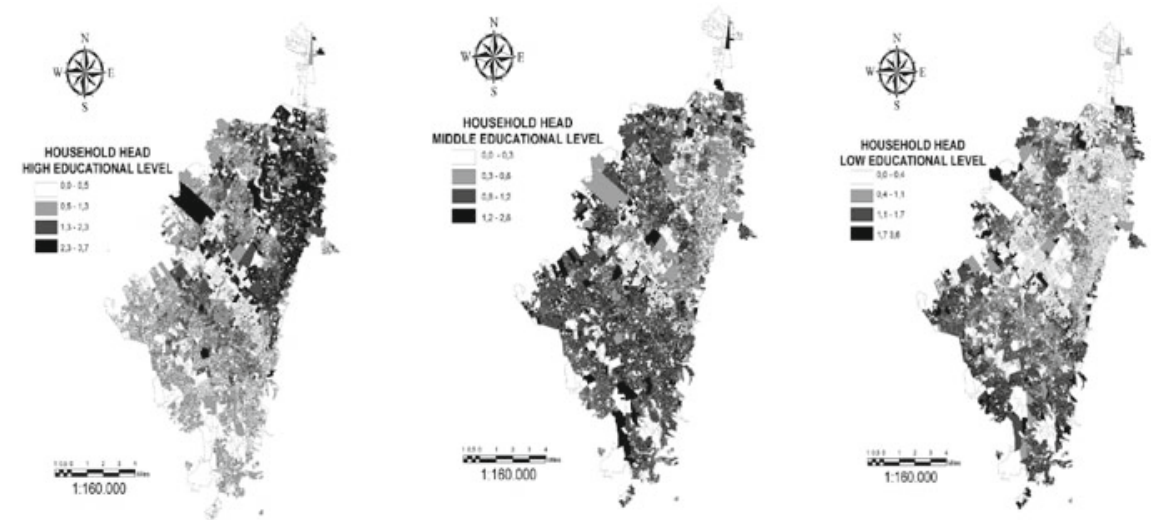

Fig. 22.3 Location quotient for household leader by high, medium, and low education level in Bogotá, 2005. Source Elaboration by the authors based on Population Census DANE (2005)

These findings are similar with discovered those of census sector geographic scale for the average years of education of the household head which in 2005 rendered a higher value (0.72) in relation with the other variables, such as poor households and households by socioeconomic class (Aliaga and Álvarez 2010).

Regarding the inequality index, income inequality in Bogotá is $56 \%$, which coincides with other works for the same year and a different source (DANE 2012). This result, in addition to suggesting that inequality is related to segregation, shows which 


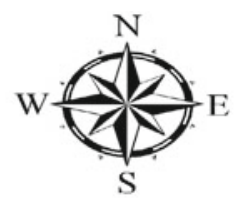

INCOME DISTRIBUTION 2005

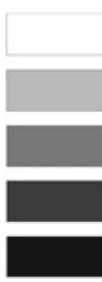

$0,0-192,9$

$192,9-203,6$

$203,6-213,0$

$213,0-231,1$

$>231,1$

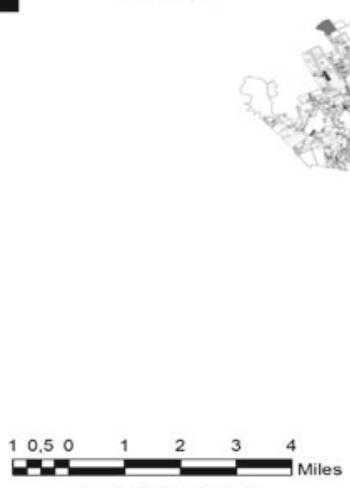

1:160.000
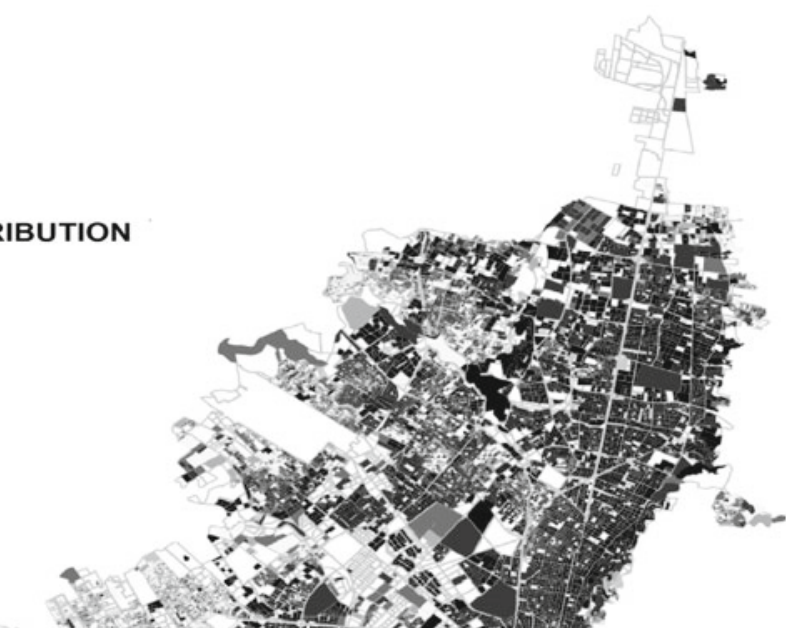

1.160 .000

Fig. 22.4 Estimation of per capita current income in Bogotá, 2005. Source Elaboration by the authors based on ECV-B2007 (DANE 2007) and Population Census DANE (2005)

the neighborhoods with a higher concentration of high and low-income populations when considering the spatial distribution of the current estimation of income at block scale (see Fig. 22.4). Nevertheless, to claim that inequality is a direct cause of segregation may be an arbitrary statement when taking into account that it is possible that land and housing markets are responsible for socio-spatial segregation in Bogotá (Aliaga and Álvarez 2010; Almonacid 2014; Salas 2008). The latter is due to the strong relationship between public and private agents in shaping which individuals have access to certain types of housing and which individuals don't (Salas 2008). The former is due to the relegated role of the State in housing provision and promotion, mainly through subsidies and norm setting, i.e., the state's ability to influence the land and housing markets is not relevant. Rather, private agents are the key players who develop real estate projects and who provide housing for those population groups that want to and are able to buy homes at a higher price point in order to obtain maximum 
gains. This is achieved by private agents localizing medium-high socioeconomic groups in a differential and fragmentary way. This is the way in which residential segregation plays a role in the functioning of land and housing markets.

\subsection{Conclusions}

The socio-spatial segregation analysis for Bogotá presented new insights into the segregation dynamics of the city. Bogotá is commonly referred to as the city with a rich north and a poor south, when considering the education levels of the heads of the households and average per capita income. Despite these two differentiated macro areas of Bogotá, it is clear that small concentrations of individuals with a low level of education and a low income can be found across the entire city. This is not evident in the case of individuals with higher educational levels. This group mainly resides in the Northeast of the city. It is important to mention that despite the fact that segregation exists between the North and South in terms of social status, segregation is also amplified at a small scale. The fact that education level segregates the population in a similar way to per capita income implies that it is possible that these two variables have an effect on social capital due to the fact that when education segregates it may affect mobility and social integration (Kaztman 2001).

Accordingly, it can be said that land value may be a more significant determinant of land concentration for a few individuals rather than income, due to the fact that land policies may be able to counteract such concentration. This is because there are housing and territorial organization policies, as well as norms and laws, which egulate the pursuit for ran urban equality in order to eliminate privileges in the distribution of urban equipment (of education, sport, culture, others) independently of the localization of a certain population group.

This is how the actions of social agents, such as urbanists, have changed the way in which segregation manifests, because they have intervened in the city under the logic of land and housing market liberalization. This liberalization manifests as the differentiation of segregated residential areas that have an effect on the social structure of class by making it more complex. In turn, this complexity reproduces certain production relations (between capitalist and the proletariat) and at the same time reinforces class diversity, which may stress the symbolic value that individuals give to the territory by means of their behavior and in the choice of different types of housing, a consideration that has been scarcely studied and that would be important to address in future investigations about the subjective dimensions of segregation. 


\section{References}

Ábramo P (2003) La teoría económica de la favela: cuatro notas sobre la localización residencial de los pobres y el mercado inmobiliario informal. Ciudad y Territorio: Estudios TerritorialesXXXV:273-294

Alcaldia Mayor de Bogotá , Secretaria Distrital de Planeación (2010) Población y desarrollo urbano 23:52. https://www.sdp.gov.co/portal/page/portal/PortalSDP/InformacionTomaDecisi ones/Estadisticas/Bogot\%E1CiudaddeEstad\%EDsticas/2010/DICE106-CartillaPobDesalloUrb ano-2010.pdf

Alessandri AF (2013) A Prática Espacial Urbana Como Segregação e o "Direito à Cidade" Como Horizonte Utópico. In: A CIDADE CONTEMPORÂNEA SEGREGAÇÃO ESPACIAL, Sao Pulo, Context, pp 96-110

Aliaga L, Álvarez MJ (2010) Segregación Residencial en Bogotá a través del Tiempo y diferentes escalas. Lincoln Institute of Land Policy

Almonacid J (2014) Lógicas contemporáneas de la segregación residencial en tres casos representativos de Bogotá DC. Bdigital.Unal.Edu.Co. Universidad Nacional de Colombia

Amézquita L, Sánchez M, Abaunza G (2017) Segregación residencial y transmilenio. In: Rubiano M (ed) Segregación socioespacial. Miradas cruzadas desde Río de Janeiro, Bogotá y sus áreas de influencia metropolitana. Universidad Piloto de Colombia, Bogotá D.C, p 450

Aprile J, Mosquera G (1984) Clases, Segregación y Barrios, 1st edn. Universidad del Valle, Cali

Buzai G (2003) Mapas Urbanos Sociales. Lugar Editorial, Buenos Aires

Cardeño F (2007) Historial del desarrollo urbano del centro de Bogotá (localidad de Los Mártires). Alcaldía Mayor de Bogotá, Bogotá D.C. https://www.culturarecreacionydeporte.gov.co/observ atorio/documentos/investigaciones/estadosArte/HistoriaBta_Martires.pdf

Castells M (2008) La Cuestión Urbana. Siglo Veintiuno Editores, S.A, México

DANE (2005) Censo general 2005. Bogotá D.C.

DANE (2007) Encuesta de Calidad de Vida-Bogotá 2007. Bogotá D.C.

DANE (2012) Cifras departamentales de pobreza monetaria y la desigualdad. Bogotá D.C.

De Mattos C (2002) Santiago de Chile de cara a la Globalización: ¿otra ciudad? Revista de Sociologia e Política19:31-54. https://doi.org/10.5380/rsp.v19i0

De Mattos C (2012) Notas sobre una falsa disyuntiva: redensificación de las áreas centrales versus dispersión urbana. Tendencias recientes, evidencia empírica. Instituto de Estudios Urbanos y territoriales

De Queiroz L (2003) Segregação Residencial e Políticas Públicas: Análise do Espaço Social da Cidade na Gestão do Território. Cidades - Comunidades e Territórios (6):33-50. https://cidades. dinamiacet.iscte-iul.pt/index.php/CCT/login?source=/index.php/CCT/article/view/178/165

Dureau et al (2012) Evolución de la intensidad y de las escalas de la segregación residencial en Bogotá: un análisis comparativo con Santiago de Chile y Sao Paulo. In: X seminario ACIUR (Asociación Colombiana de Investigadores Urbano Regionales), pp 1-20

Elorza A (2013) La dimensión subjetiva de la segregación residencial socioeconómica: las representaciones sociales sobre el territorio. Revista Vivienda y Ciudad 1:123-133

Fuentes J (2010) Desigualdad, segregación socio-espacial y precios del suelo en la ciudad Latinoamericana. El caso de Bogotá en los Años Noventa. Revista UIS. Humanidades 38(1):109-126

Fuentes L (2012) Ciudades y sociedades urbanas en transformación. Competitividad, reestructuración y cohesión social en Bogotá, Lima y Santiago en las últimas décadas. Pontificia Universidad Católica de Chile

García L, Gascón D (2016) Portafolio de mapas. Bogotá D.C, Equipo de integración de documentos POT

Garrocho C, Campos-Alanís J (2013) Réquiem por los indicadores no espaciales de segregación residencial. Papeles De Poblacion 19(77):269-300

Howell-Moroney M (2005) The geography of opportunity and unemployment: an integrated model of residential segregation and spatial mismatch. J Urban Affairs 27(4):353-377. https://doi.org/ 10.1111/j.0735-2166.2005.00234.x-i1 
Janoschka M, Glasze G (2003) Urbanizaciones cerradas: un modelo analítico. CIUDADES, Puebla

Kaztman R (2001) Seducidos y abandonados. El aislamiento social de los pobres urbanos. Revista de La CEPAL (75):171-189

Kaztman R (2003) La dimensión espacial en las políticas de superación de la pobreza urbana. Serie Medio Ambiente y Desarrollo, vol 59. Santiago de Chile

Lefebvre H (1976) Espacio y Política. El Derecho a la Ciudad II. Ediciones Península, Barcelona

Lefebvre H (1978a) De lo Rural a lo Urbano. Ediciones Península, Barcelona. https://doi.org/10. $1177 / 072551369203300110$

Lefebvre H (1978b) El Derecho a la Ciudad. Ediciones Península, Barcelona

Martori JC, Hoberg K, Surinach J (2006) Población inmigrante y espacio urbano. Indicadores de segregación y pautas de localización. Eure32(97):49-62. https://doi.org/10.4067/S0250-716120 06000300004

Massey D, Denton N (1988) The dimensions of residential segregation. Soc Forces67(2):281-315. https://isites.harvard.edu/fs/docs/icb.topic98848.files/massey.denton.pdf

Medina C, Morales L, Núñez J (2008) Quality of life in urban neighborhoods in Colombia: The Cases of Bogotá and Medellín. Borradores de Economía (536)

Molina L (2008) Barrancabermeja: segregación socioespacial y desequilibrios funcionales. Cuadernos de Vivienda y Urbanismo 1(2):332-347. Retrieved from http://scholar.google.com/ scholar?hl=en\&btnG=Search\&q=intitle:Barrancabermeja + :+segregaci? + +socioespacial+y+des equilibrios+funcionales\#0

Moura R (2003) Inversiones urbanas en el contexto de la competitividad y globalización: los eventos en Curitiba. EURE (Santiago) 29(86):51-68. https://doi.org/10.4067/S0250-716120030 08600003

Reardon S, O'Sullivan D (2004) Measures of spatial segregation. Sociol Methodol 34(1):121-162. https://doi.org/10.1111/j.0081-1750.2004.00150.x

Rubiano M (2017) Segregación socioespacial y dinámica metropolitana desde las relaciones BogotáSoacha: una reflexión a partir del caso de Ciudad Verde. In: M. Rubiano (ed) Segregación socioespacial. Miradas cruzadas desde Río de Janeiro, Bogotá y sus áreas de influencia metropolitana, pp 141-212). Universidad Piloto de Colombia, Bogotá D.C.

Ruiz-Tagle J (2016) La segregación y la integración en la sociología urbana: revisión de enfoques y aproximaciones críticas para las políticas públicas. Revista INVI 31(87):9-57. https://doi.org/ 10.4067/INVI.V0I0.1070

Ruiz-Tagle J, López E (2014) El estudio de la segregación residencial en Santiago de Chile: revisión crítica de algunos problemas metodológicos y conceptuales. EURE 40(119):25-48

Sabatini F (2003) La segregación social del espacio en las ciudades de América Latina. Banco Interamericano de Desarrollo 1-41. https://www.iadb.org.uy/sds/doc/SOCSabatiniSegregacion. pdf

Sabatini F, Cáceres G (2005) Relación entre Promoción Inmobiliaria y Segregación Residencial: Giros Insospechados de la Ciudad Latinoaméricana. Lincoln Institute of Land Policy. https://doi. org/10.1017/CBO9781107415324.004

Sabatini F, Wormald G, Sierralta C, Peters P (2008) Segregación Residencial en Santiago: Tendencias 1992-2002 y efectos vinculados con su escala geográfica. In Sabatini F, Salcedo R, Wormald G (eds) Tendencias Segregación en las Principales Ciudades Chilenas. Santiago de Chile: Instituto Nacional de Estadísticas, Pontificia Universidad Católica de Chile

Salas A (2008) Residential segregation and housing production in Bogota, between perceptions and realities. Université de Poitiers. https://tel.archives-ouvertes.fr/tel-00303317

Secretaría Distrital de Planeación (2007) Segregación Socioeconómica en el Espacio Urbano de Bogotá D.C. Universidad Nacional de Colombia. Bogotá D.C.

Secretaría Distrital de Planeación (2011) Segregación Socioespacial En Bogotá 2011. Indicadores y Medición. Bogotá D.C. Retrieved from http://es.scribd.com/doc/94922064/Boletn-39-SEGREG ACIN 
Secretaría Distrital de Planeación (2013) Segregación Socioeconómica en el Espacio Urbano de Bogotá D.C. Universidad Nacional de Colombia, Secretaría Distrital de Planeación. Bogotá D.C: Secretaría Distrital de Planeación, Universidad Nacional de Colombia

Shevky E, Bell W (1955) Social area analysis: theory, illustrative application and computational procedures. Standford University Press, Stanford

Shevky E, Williams M (1949) The social area of Los Angeles: analysis and typology. University of California Press, Berkeley

Torres C, Gaviria A, Zuñiga D, Vargas J, Nieto D, Bustos S (2009) Ciudad informal colombiana Barrios construidos por la gente. Universidad Nacional de Colombia

Velasquez C (2011) Localización y distribución de la vivienda social en la ciudad de medellín. Una Mirada Desde la Segregación Espacial. Universidad Nacional de Colombia, Sede Medellín

Open Access This chapter is licensed under the terms of the Creative Commons Attribution 4.0 International License (http://creativecommons.org/licenses/by/4.0/), which permits use, sharing, adaptation, distribution and reproduction in any medium or format, as long as you give appropriate credit to the original author(s) and the source, provide a link to the Creative Commons license and indicate if changes were made.

The images or other third party material in this chapter are included in the chapter's Creative Commons license, unless indicated otherwise in a credit line to the material. If material is not included in the chapter's Creative Commons license and your intended use is not permitted by statutory regulation or exceeds the permitted use, you will need to obtain permission directly from the copyright holder. 